\title{
Liudmyla luzva
}

Taras Shevchenko National University of Kyiv

(iD) https://orcid.org/0000-0003-1448-5478

$\triangle$ luydmilay@gmail.com

\section{DISTANCE EDUCATION AND RETURN TO SCHOOLS IN THE MINDS OF UKRAINIAN SCHOOLCHILDREN: A BRIEF REPORT ON THE RESULTS OF THE RESEARCH}

\section{ZDALNA EDUKACJA I POWRÓT DO SZKOŁY W OPINII UKRAIŃSKICH UCZNIÓW: KRÓTKIE SPRAWOZDANIE Z BADAŃ}

DOI: 10.24917/ycee.2021.12.24-33

\begin{tabular}{|c|c|}
\hline Abstract: & $\begin{array}{l}\text { As a result of the coronavirus pandemic, many social systems have been shaken. Among them is education system. } \\
\text { Over the past two years, much research has focused on the problems of the pandemic period which have arisen both } \\
\text { in educators and students. However, there is still no comprehensive understanding of them. The NAWA-funded project } \\
\text { "Identifying Barriers to Ukrainian and Polish Students Returning to School" has led to a representative study of distance } \\
\text { education among Ukrainian schoolchildren. The research was constructed on a classical sociological methodology based } \\
\text { on computer-assisted personal interviews (CAPI). The aim was to identify problems of distance education and barriers } \\
\text { that could prevent schoolchildren from returning to the classical form of education (both social and mental health). One } \\
\text { of them was the fatigue of distance learning and the difficulty of perceiving educational material through the screen. The } \\
\text { results of the study also showed different types of inequalities in access to educational services, their quality, and so on. }\end{array}$ \\
\hline Keywords: & school education, schoolchildren, distance learning, COVID-19 pandemic, Ukraine. \\
\hline Abstrakt: & $\begin{array}{l}\text { W wyniku pandemii koronawirusa wiele systemów społecznych zostało wyprowadzonych z równowagi. Wśród nich } \\
\text { znalazł się system edukacji. W ciągu ostatnich dwóch lat wiele badań koncentrowało się na problemach funkcjonowania } \\
\text { zdalnej edukacji w czasie pandemii. Badania realizowano zarówno wśród nauczycieli, jak i uczniów. Jednak nadal } \\
\text { nie ma pełnej wiedzy na temat skutków zdalnej edukacji. W ramach finansowanego przez NAWA projektu „Identy- } \\
\text { fikacja barier powrotu do szkoły wśród ukraińskich i polskich uczniów" przeprowadzono reprezentatywne badanie } \\
\text { zdalnego nauczania wśród ukraińskich uczniów. Badanie zostało skonstruowane w oparciu o klasyczną metodologię } \\
\text { socjologiczną opartą na wspomaganych komputerowo wywiadach osobistych (CAPI). Celem było zidentyfikowanie } \\
\text { problemów nauczania online oraz barier, które mogą uniemożliwiać uczniom powrót do tradycyjnej formy edukacji } \\
\text { (kondycja społeczna, psychiczna). Konsekwencjami zdalnej edukacji były np. zmęczenie nauką na odległość i trudność } \\
\text { w odbiorze materiałów edukacyjnych w trakcie lekcji online. Wyniki badania wykazały również różnego rodzaju } \\
\text { nierówności w dostępie do zdalnej edukacji i jej jakości. }\end{array}$ \\
\hline & dukacja szkolna, uczniowie, zdalna edukacja, pandemia COVID-19, Ukraina. \\
\hline
\end{tabular}


Ticons he COVID-I9 pandemic has challenged most societal systems. It probably mostly influenced medical system and education system. According to CEDOS, the transition to distance learning in the wake of the COVID-I9 pandemic has led to a deterioration in the quality and accessibility of education, as well as to exacerbating a number of educational inequalities. At the beginning of the pandemic, $90 \%$ of schools around the world were closed. In the spring of 2020 , all educational institutions in Ukraine switched to distance learning. A few months later, an "adaptive quarantine" was introduced in Ukraine, which provided for the division of Ukraine into zones of epidemiological security: green, yellow, orange, and red. Accordingly, general secondary education institutions constantly switched from distance to blended learning and vice versa, while higher education institutions mostly remained at distance learning (Nazarenko, Polishchuk, 202I). During the pandemic period, Ukrainian scholars, as well as scholars around the world, have conducted much research devoted to educational issues (Osvita i pandemiia, 2020; Yeremenko, 2020; Otsinka stavlennia do problemy koronavirusu Covid-ı ta karantynnykh zakhodiv, 2020; Długosz et al., 2020). One of the largest and one dedicated to the remote period and children is the project "The Impact of the COVID-rg Pandemic on Daily Childhood Practices" (Polek, Sanina, Sobol', 202I). It is important to remember that such turbulence has become commonplace for schoolchildren, the vast majority of whom are at a very young age. It has strongly affected both their perception of education in general and their mental health. Under such conditions, the understanding of how to make the readaptation of schoolchildren to the classical offline education system non-traumatic became especially important. This task has been performed within the framework of the project funded by the Polish National Agency for Academic Exchange titled "Identification of Barriers Hindering Ukrainian and Polish Schoolchildren's Return to Schools" (Intervention Grants Programme, BPN/GIN/202I/I/00012/U/O000I).

\section{Research Methodology}

The research was based on various research questions which concerned problems of distance learning period and returning to school. Some of them will be disclosed in this article:

- Which problems did schoolchildren have with distance learning?

- What are the main barriers to studying during distance learning?

To achieve intended research goals, the best method is the implementation of a survey conducted according to the CAPI (Computer Assisted Personal Interview) methodology. The proposed research method allows the respondent to contact a qualified interviewer who ensures that the entire questionnaire is completed and encourages the respondent to provide thoughtful answers. Thanks to this method, the computer system verifies correctness of entered data and guarantees quick preparation of a report and statistical analysis of obtained results. This method also allows for the presentation of multimedia content and enables the extension of the scope of research compared to traditional methods of opinion research. Undoubtedly, it is a method that guarantees high accuracy and reliability of variable measurements. At the same time, it allows for quick collection of data ready for analysis.

What is very important, the survey methodology enables testing of a representative sample of older and younger schoolchildren from all over the territory of two countries (Poland and Ukraine). Thanks to the randomly selected sample, taking into account criteria such as social status, gender, or place of residence, we were finally able to find out about problems faced by all social classes and income groups. This method also made it possible to conduct interviews at the respondents' homes, which is conducive to reporting problems and greater reflection and 
gives an interviewer the opportunity to assess the situation during the research.

So, from August I5 to 27, 2021, the Kyiv International Institute of Sociology (KIIS) conducted an all-Ukrainian survey of schoolchildren. Computer-assisted personal interviews (CAPI) interviewed $\mathrm{r} .022$ respondents living in 78 settlements in all regions of Ukraine (except the Autonomous Republic of Crimea) in a stochastic sample, representative of quotas for the region and region of residence, type of settlement, sex, and age. In Luhansk and Donetsk oblasts, surveys were conducted only in the territories controlled by Ukraine. Statistical sampling error-with a probability of 0.95 and a design effect of I.I. Analysis of the data was carried out using SPSS.

\section{Research Results}

\section{Technical Conditions for Online Education}

Ukrainian schoolchildren stated that they have their own desk for school assignments (86\%) and constant access to the Internet (8I\%). Also, a significant proportion of schoolchildren have laptops (61\%) and a room where they can study (61\%). A large proportion of Ukrainian families still have a desktop PC (4I\%). Among the devices that may be (or are) useful in the learning process at home, respondents rarely indicated a printer (I8\%) and a scanner (6\%).

\section{Assessment of the Quality of Classes}

In fact, for the first time, Ukrainian schoolchildren had a long systematic experience of participating in distance learning. Comparing traditional school lessons in classrooms and distance lessons, schoolchildren often noted that online lessons were uninteresting and of poor quality $(43 \%)$ or were the same as lessons in classes? $(34 \%)$.

\section{The Pros and Cons of Online Education}

The research focused on the study of the pros and cons of distance education. Among the main advantages of distance education, Ukrainian schoolchildren listed:

- $75 \%$ agree that the lack of need to get together or go to school was positive, and that there

Which of the following items or devices are in your home?

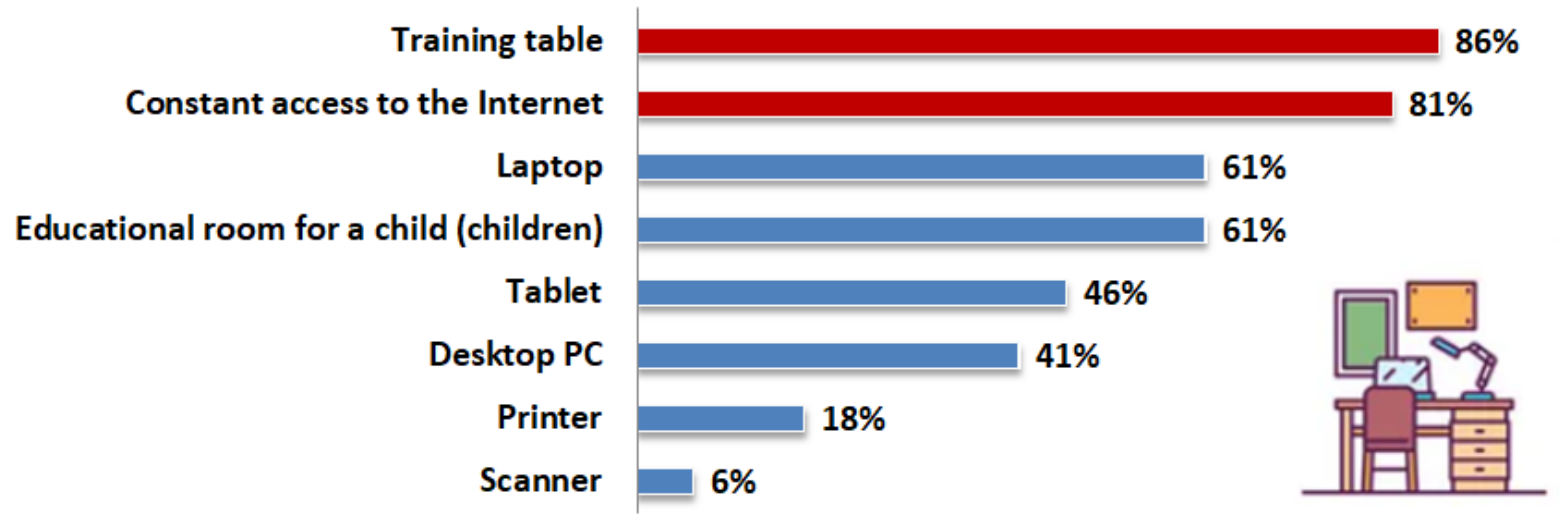

Figure 1. The items or devices which respondents have in their home 


\section{Online lessons, compared to traditional school lessons, were...}

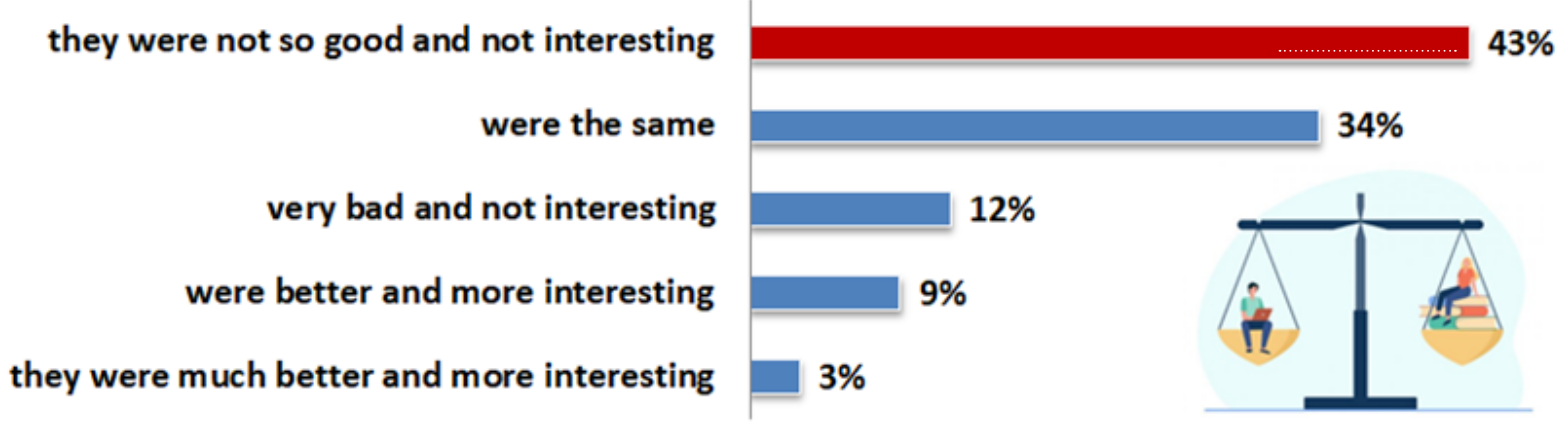

Figure 2. Comparing online lessons and traditional school lessons

Source: constructed by the author on research data

was more free time ( $37 \%$ completely agree and $33 \%$ rather agree);

- $70 \%$ agree that the positive thing was the opportunity to sleep more and that there was no need to hurry anywhere (37\% completely agree and $33 \%$-rather agree);

- $67 \%$ agree that the positive thing was that distance learning is safer because it protects against the danger of getting COVID-is (32\% completely agree and $35 \%$ rather agree);
- $59 \%$ agree that the positive thing was that during distance learning they could use the help of parents and siblings ( $22 \%$ completely agree and $37 \%$ rather agree);

- $52 \%$ agree that the positive thing was that during distance learning they had fewer learning responsibilities ( $17 \%$ completely agree and $35 \%$ rather agree);

- $48 \%$ agree that the positive thing was that due to distance learning they had more time for

\begin{tabular}{|c|c|c|c|c|c|c|c|c|}
\hline $\begin{array}{l}\text { During distance leaming I could sleep more. There was no need to hurry } \\
\text { anywhere. }\end{array}$ & 9\% & $11 \%$ & $10 \%$ & \multicolumn{2}{|c|}{$33 \%$} & \multicolumn{3}{|c|}{$37 \%$} \\
\hline $\begin{array}{l}\text { During distance leaming, I was able to use the help of my parents and } \\
\text { slblings. }\end{array}$ & $13 \%$ & \multicolumn{2}{|c|}{$13 \%$} & $15 \%$ & \multicolumn{2}{|l|}{$37 \%$} & \multicolumn{2}{|c|}{$22 \%$} \\
\hline Distance learning is safer because I can't get COVID-19. & $9 \%$ & $9 \%$ & $15 \%$ & \multicolumn{2}{|r|}{$35 \%$} & \multicolumn{3}{|c|}{$32 \%$} \\
\hline I'm used to distance learning and I don't want to go back to school. & \multicolumn{3}{|c|}{$42 \%$} & \multicolumn{2}{|r|}{$24 \%$} & $14 \%$ & $12 \%$ & $7 \%$ \\
\hline During distance leaming, I had fewer study responsibilities. & $14 \%$ & \multicolumn{2}{|r|}{$19 \%$} & $16 \%$ & \multicolumn{2}{|c|}{$35 \%$} & \multicolumn{2}{|c|}{$17 \%$} \\
\hline $\begin{array}{l}\text { I didn't have to pack up for school, I didn't have to go to school, and I had } \\
\text { more time for myself. }\end{array}$ & $5 \% \quad 7 \%$ & \multicolumn{2}{|c|}{$13 \%$} & \multicolumn{2}{|c|}{$38 \%$} & \multicolumn{3}{|c|}{$37 \%$} \\
\hline $\begin{array}{l}\text { Thanks to distance learning, I had more time for family, classmates and } \\
\text { friends. }\end{array}$ & $10 \%$ & \multicolumn{2}{|c|}{$13 \%$} & $19 \%$ & \multicolumn{2}{|l|}{$23 \%$} & \multicolumn{2}{|l|}{$25 \%$} \\
\hline
\end{tabular}

Figure 3. The pros of online education

Source: constructed by the author on research data 
families, classmates, and friends (25\% completely agree and $23 \%$ rather agree).

The researchers asked schoolchildren to express their views on hypothetical shortcomings of distance education. Some of them were indeed assessed as shortcomings, others-not. Thus, among the main disadvantages of distance education, Ukrainian schoolchildren called:

- $65 \%$ of schoolchildren agree that during distance learning their relationship with teachers deteriorated (29\% completely agree and 36\% rather agree);

- $54 \%$ of schoolchildren agree that during distance learning their relationships with classmates deteriorated ( $18 \%$ completely agree and $36 \%$ rather agree);

- $53 \%$ of schoolchildren agree that during distance learning they could not fully participate in online lessons due to health problems ( $17 \%$ completely agree and $36 \%$ rather agree);

- only $19 \%$ agree that they are used to distance learning and do not want to go back to school ( $7 \%$ completely agree and $\mathrm{i} 2 \%$ rather agree). However, the schoolchildren did not agree with other disadvantages that could be inherent in the period of distance education:
- $61 \%$ of schoolchildren do not agree that during distance learning they were physically and morally exhausted ( $33 \%$ completely disagree and $28 \%$ rather disagree);

- $70 \%$ of schoolchildren do not agree that during distance learning other schoolchildren listened to what they said, and this confused them ( $38 \%$ completely disagree and $32 \%$ rather disagree);

- $77 \%$ of schoolchildren do not agree that during distance learning they spent too much time using a computer/laptop/tablet ( $44 \%$ completely disagree and $33 \%$ rather disagree);

- $74 \%$ of schoolchildren do not agree that during distance learning they could not fully understand the material of online lessons $(45 \%$ completely disagree and $29 \%$ rather disagree);

- $82 \%$ of schoolchildren disagree that during online lessons it was difficult for them to focus on what teachers were saying ( $59 \%$ completely disagree and $23 \%$ rather disagree).

\section{Level of Engagement in Online Education}

In general, $51 \%$ of schoolchildren rated the experience of distance education as negative and $40 \%$

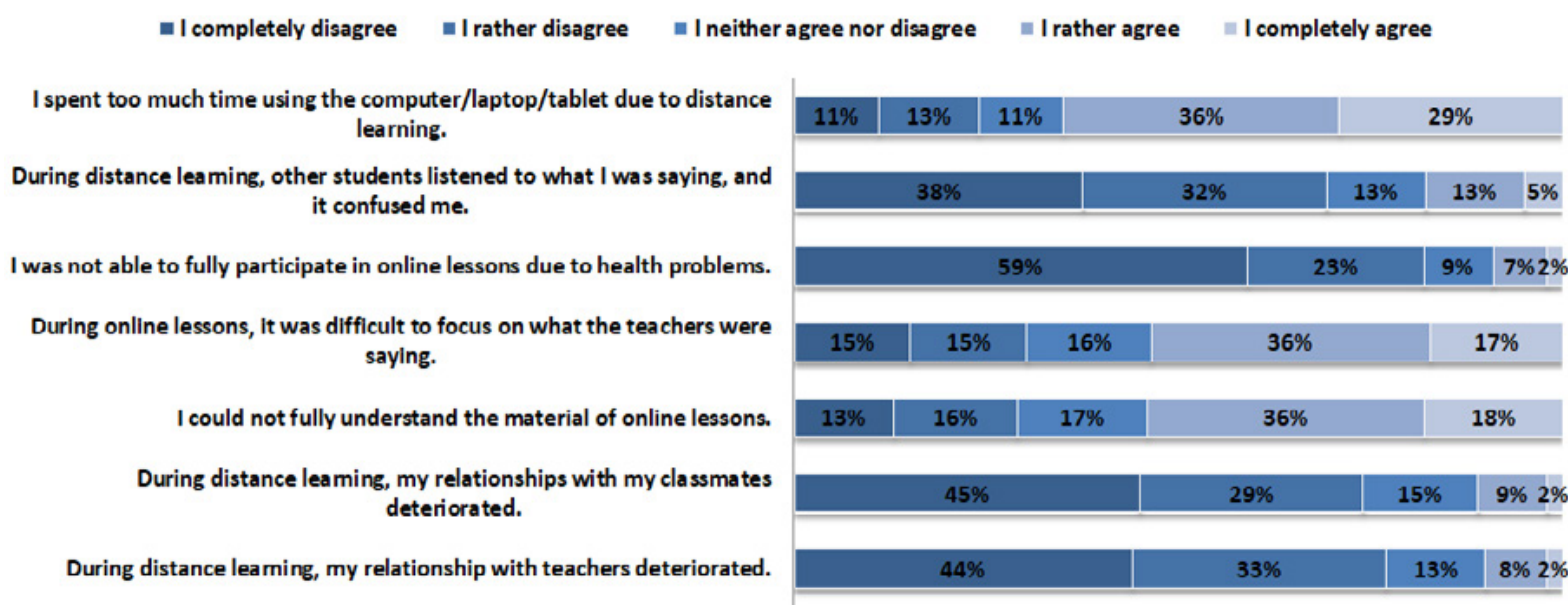

Figure 4. The cons of online education

Source: constructed by the author on research data 


\section{Distance learning in 2021 as for me...}

- liked/positive experience $\square$ did not like/negative experience $\square$ hard to tell

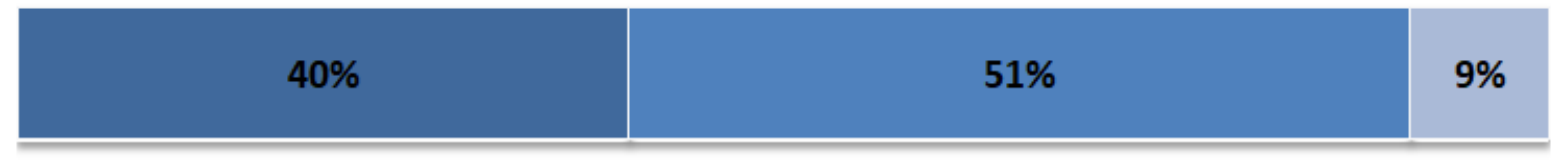

Figure 5. Assessment of distance education by respondents

Source: constructed by the author on research data

as positive. $9 \%$ of schoolchildren found it difficult to determine their assessment. It is noteworthy that the gap between negative and positive assessments is not too large. In national surveys, the percentage of those who negatively evaluate distance education is usually higher. Thus, in the Active Group survey, 40.3\% of Ukrainians said that they had a negative attitude towards distance education and $17 \%$ said it was rather negative (Yeremenko, 2020). In the New Image Marketing Group survey, 30\% of surveyed Ukrainians have a negative attitude towards distance learning and another $37 \%$ rate it rather negatively (Otsinka stavlennia do problemy koronavirusu, 2020, p. 23).

Also, $59 \%$ of schoolchildren confirmed that they take into account the equipment of their house/apartment with a computer, laptop, and the quality of the Internet. In the vast majority of cases they allowed the respondents to completely fulfill their learning responsibilities during distance learning. $27 \%$ of schoolchildren said that they allowed it faster, i.e., majority of the respondents confirmed the possibility of performing school duties during the distance period of education.

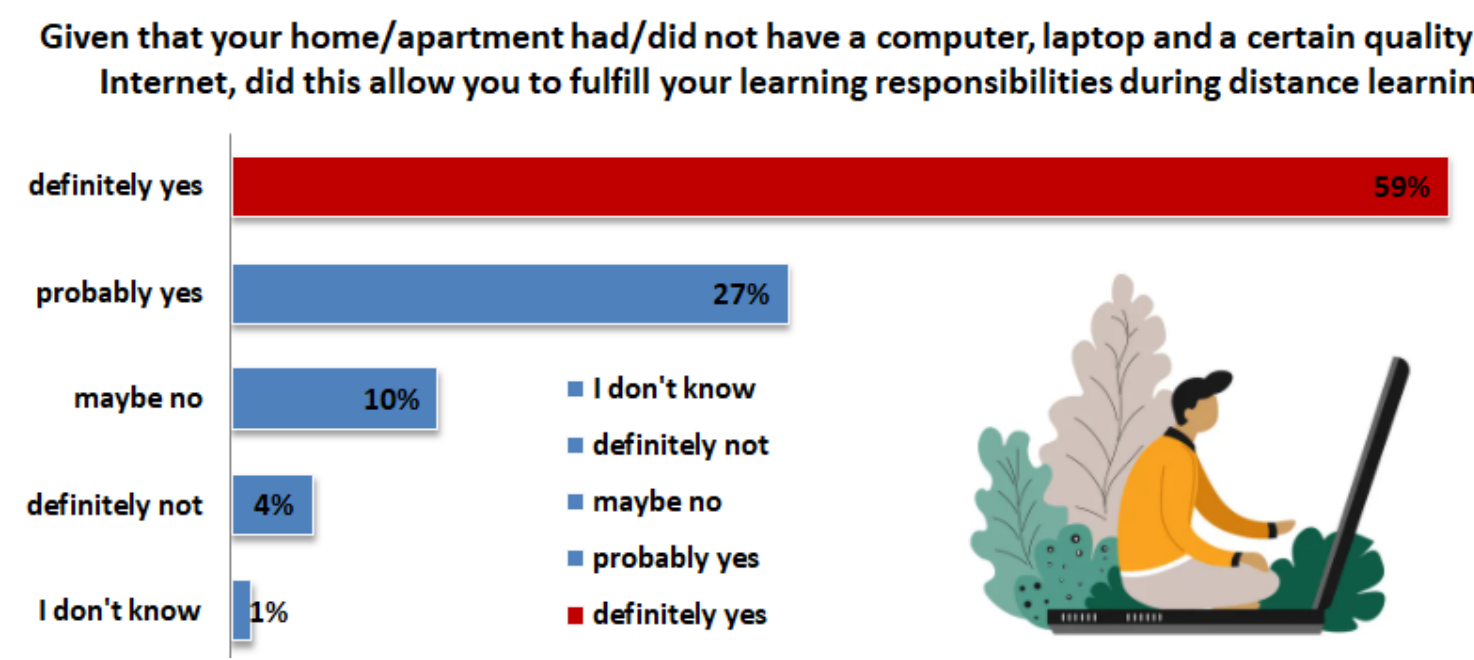

Figure 6. Fulfilling learning responsibilities during distance period of studying

Source: constructed by the author on research data 


\section{Attendance at Online Classes and Reasons for Absenteeism}

Most of schoolchildren in the study indicated that they attended all online lessons (47\%) and most online lessons $(41 \%)$. Only $3 \%$ of schoolchildren found it difficult to attend online lessons and $9 \%$ attended only some of them.
The most common reasons for skipping online lessons were that some lessons were uninteresting (16\%), that the students were tired of distance learning (13\%), and that they were sick (II\%).

Schoolchildren who entered their individual answer to the question about the reasons for skipping online lessons often pointed to poor Internet connection, the fact that teachers did not

\section{During the distance learning I participated:}

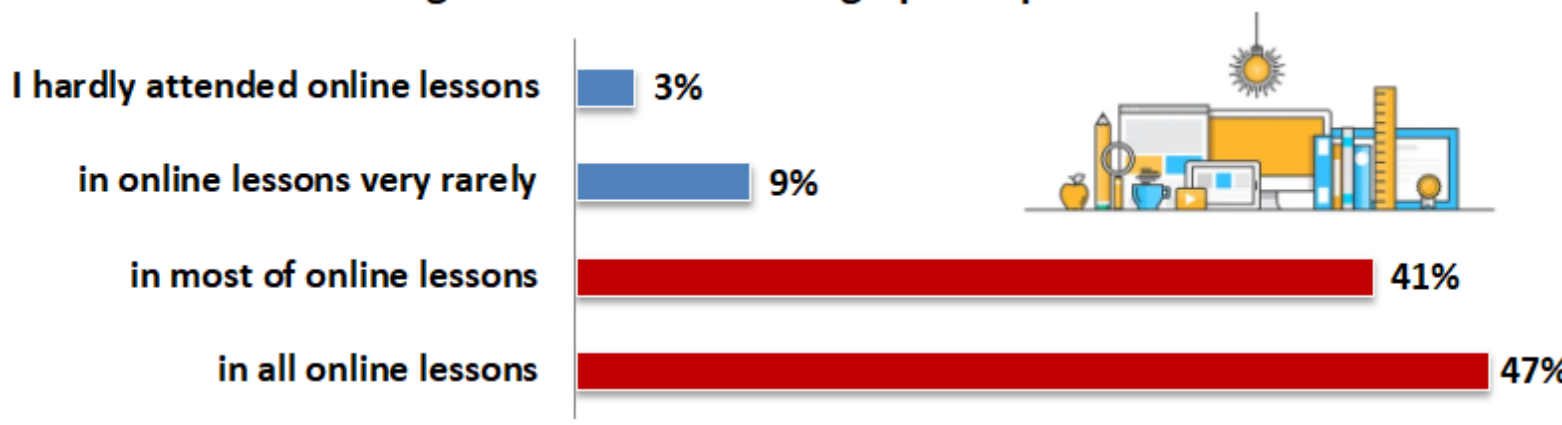

Figure 7. Participating in online lessons during distance period of studying

Source: constructed by the author on research data

If you could not attend all the online lessons what was the reason for this?

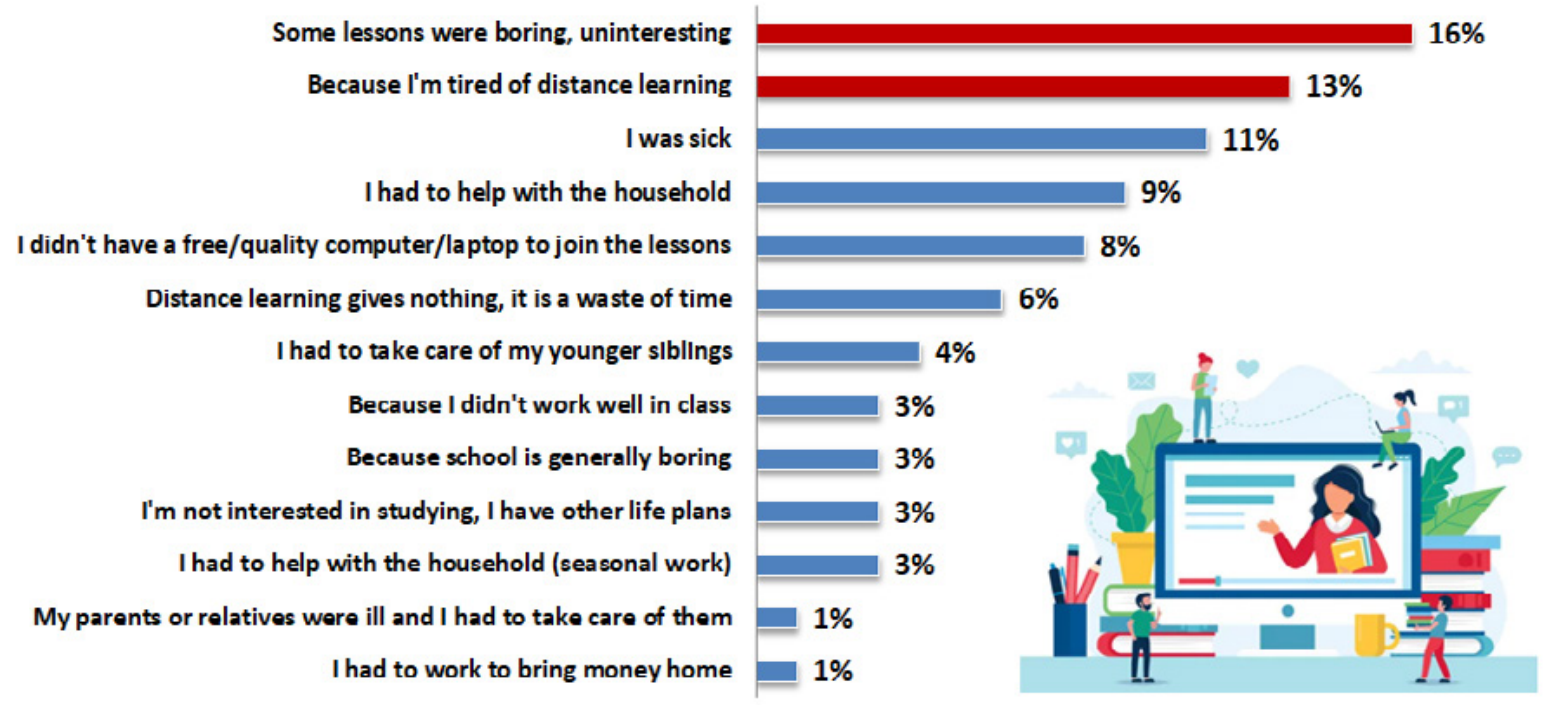

Figure 8. Reasons for non-attendance of online lessons during distance period of studying

Source: constructed by the author on research data 


\section{couldn't join the lesson \\ I didn't have Zoom \\ power outage \\ problems with loading $/$ operation of the site \\ I don't remember $/$ it is difficult to answer gadget issue $/$ lack thereof \\ bad Internet connection \\ I forgot about the lesson/confused the time \\ there was no teacher at an online lesson \\ a link wasn't sent to the lesson \\ laziness \\ I went about my business}

Figure 9. Reasons for non-attendance of online lessons during distance period of studying (open question)

Instrument: Word/tOut (https://worditout.com/)

Source: constructed by the author on research data

conduct lessons, various problems with joining online lessons (untimely sent links, passwords, etc.), and turning off the lights in the areas of residence.

\section{Willingness to Go Back to School}

Schoolchildren note that their desire to return to normal schooling (i.e., in classrooms) is much greater $(50 \%)$ after their staying at home and distance education. $35 \%$ of schoolchildren indicated that the desire to return to school is the same as the distance learning experience. $12 \%$ of schoolchildren said that their desire to return to school decreased.

\section{Discussion and Conclusions}

First of all, it should be emphasized that Ukrainian schoolchildren have entered the period of

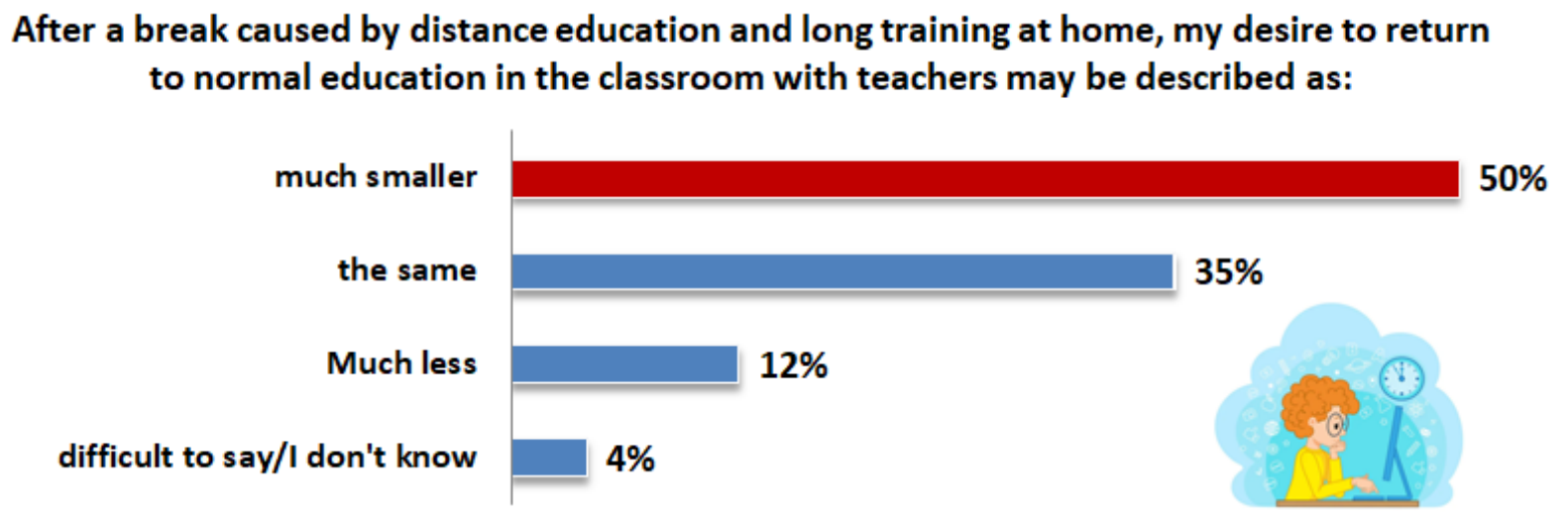

Figure 10. Schoolchildren's desire to return to offline education

Source: constructed by the author on research data 
distance education having unequal opportunities. Serhii Horbachov, the Educational Ombudsman, notes that the quality of education is directly related to access to it, the organization of distance learning, and the ability of schoolchildren to acquire knowledge and acquire in general. $\mathrm{He}$ states that, unfortunately, for schoolchildren, especially general secondary education, inequality of access to education in Ukraine, and the world during the pandemic only worsened (Horbachov, 202I). However, most of the schoolchildren who took part in the study stated that they had their own desk and Internet access as well as a laptop and a room. One of the important reasons that created inequality was access (constant) to high-quality high-speed Internet. Among the reasons for the absence during distance lessons, in the open question schoolchildren most often pointed out problems with the Internet connection. A methodological feature of the study was that the alternatives did not include a smartphone as a tool to use during online classes. This seems to be a disadvantage of constructing the question because a significant number of Ukrainian schoolchildren studied through smartphones. Given the small size of the screen and the specifics of consuming information from a smartphone, it should be noted that this is also a kind of inequality compared to those schoolchildren who consumed information from a computer screen.

More than half of Ukrainian schoolchildren said that they consider the experience of distance education negative and online lessons uninteresting. Such data are confirmed by other sociological studies on schoolchildren (Markovska, 202I). This is often due to the fact that the world is becoming increasingly digital, which is happening too fast. Alvin Toffler described how technology affects social life and introduced the concept of futuroshock. That is, when under the influence of technology there are too many changes in too short time, people do not have time to adapt and are shocked (Makarenko, 202I). This is exactly the kind of futuroshock experienced by the participants of the educational process with the beginning of the pandemic.

Most of the schoolchildren indicated that during distance learning they managed to achieve their learning goals and almost half of them participated in online lessons. Global research confirms the correlation between class absences and performance (García, Weiss, 2020). In the study, schoolchildren also indicated that they assess the level of their knowledge obtained in online and offline periods approximately the same. However, the International Education Quality Survey PISA, coordinated by the Organization for Economic Development and Cooperation (OECD), showed that, for example, the average level of mathematical literacy of Ukrainian schoolchildren corresponds to the second level ( 453 points). $36 \%$ of Ukrainian schoolchildren failed to demonstrate such a level and $15.6 \%$ of them did not even reach the first level of mathematical literacy (Bakhrushyn, 2019). Distance education only worsened the level of knowledge of Ukrainian schoolchildren $26.1 \%$ of respondents in a representative sociological survey indicated this as a problem of offline education) (Osvita i pandemiia, 2020).

Among the biggest advantages of distance education, children mentioned that it was possible to sleep longer and there was no need to hurry anywhere; no need to pack a school backpack, you could save time for yourself; distance education allowed to be safe and not to be infected with COVID-19. These positive effects are questionable as they are directly related to their negative consequences-the destruction of the school day when children woke up at different times on different days. As for security, they were often in many other public spaces without attending school. However, these effects were still called positive by the student children. The same data were obtained in the project "Children's Geographies” (Polek, Sanina, Sobol', 2021, p. 40).

The biggest downside was that they spent too much time in front of computer screens and 
using other gadgets during distance learning. Two other shortcomings pointed out by a significant proportion of schoolchildren show that there were difficulties in perceiving the material online and understanding it. These shortcomings intersect with mental health issues. According to a UNICEF report, about $43 \%$ of children suffer from disorders such as anxiety and depression (On my mind, 2021, p. I8).

Thus, it can be concluded that the main difficulties in returning to ordinary school life and education lie in the areas of inequality and mental health. The children have been in different learning conditions for a long time. Often, the problems of perception, control of the children's practices and emotions lie solely with parents who also suffered from the futuroshock of the pandemic period. The state did not respond effectively to the challenge at the schoolchildren's level.

\section{Acknowledgements}

I would like to thank the head of project dr hab. prof. UP Piotr Długosz (The Pedagogical University of Krakow) for working on the research methodology and support at all stages of the research.

\section{Bibliography}

Bakhrushyn, V. (2019). Matematyka u PISA-2018: rezultaty i vysnovky. Nova Ukrainska shkola. Obtained from: https://nus.org.ua/articles/ matematyka-u-pisa-2018-rezultaty-i-vysnovky/ (retrieved 20.11.2021).

Długosz, P., Kryvachuk, L., Shyyan, 0. (2020). Social practices in the covid -19 Pandemic among Polish and ukrainian youth. Lublin: Academicon. https://doi.org/10.52097/acapress.9788362475582 (retrieved 20.11.2021).

García, E., Weiss, E. (2020). COVID-19 and student performance, equity, and U.S. education policy: Lessons from pre-pandemic research to inform relief, recovery, and rebuilding. Economic Policy Institute. Obtained from: https://www.epi.org/publication/the-consequences-of-thecovid-19-pandemic-for-education-performance-and-equity-in-theunited-states-what-can-we-learn-from-pre-pandemic-researchto-inform-relief-recovery-and-rebuilding/\# (retrieved 20.11.2021).

Horbachov, S. (2021). Nerivnyi dostup do osvity pid chas pandemii: vyklyky sohodennia. Superviziia v NUSh. Obtained from: http:// barna-consult.com/nerivnyj-dostup-do-osvity-pid-chas-pandemiyi-vyklyky-sogodennya/?fbclid=IwAR216Ws1JYIbUQ6x7gGYMQWX4PjaLwvxz-AZyQHMYx4TSHBIBWHB8CwpKBU (retrieved 20.11.2021).

Makarenko, 0. (2021). Yak dystantsiine navchannia zminylo osvitu y shcho bude dali (2021). Nova Ukrainska shkola. Obtained from: https:// nus.org.ua/articles/yak-dystantsijne-navchannya-zminylo-osvitu-j-shho-bude-dali/ (retrieved 22.11.2021).

Markovska, M. (2021). Yak ukrainski dity prozhyvaly karantyn. Nova ukrainska shkola. Obtained from: https://nus.org.ua/articles/yak-ukrayinski-dity-prozhyvaly-karantyn-tsikavi-fakty-j-11-porad-iz-doslidzhennya/ (retrieved 27.11.2021).

Nazarenko, Yu., Polishchuk, 0. (2021). Osvita v umovakh pandemii u 2020/2021 rotsi: analiz problem i naslidkiv. CEDOS. Obtained from: https://cedos.org.ua/researches/osvita-v-umovah-pandemiyi-analiz-problem-i-naslidkiv/ (retrieved 20.11.2021).

On my mind: promoting, protecting and caring for children's mental health. (2021). United Nations Children's Fund (UNICEF). Obtained from: https:// www.unicef.org/media/108036/file/SOWC-2021-executive-summary. pdf (retrieved 27.11.2021).

Osvita i pandemiia: shcho ukraintsi dumaiut pro dystantsiine navchannia ta yak otsiniuiut ZNO. (2020). Fond «Demokratychni initsiatyvy» im. Ilka Kucheriva. Obtained from: https://dif.org.ua/article/osvita-i-pandemiya-shcho-ukraintsi-dumayut-pro-distantsiyne-navchannya-ta-yak-otsinyuyut-zno (retrieved 27.11.2021).

Otsinka stavlennia do problemy koronavirusu Covid-19 ta karantynnykh zakhodiv. (2020). New Image Marketing Group. Obtained from: https://newimage.org.ua/wp-content/uploads/2020/10/\% Do\%97\%Do\%B2\%D1\%96\%D1\%82_\%D0\%95\%D0\%BA\%D1\%8 1\%Do\%BF\%D1\%80\%D0\%B5\%D1\%81_\%Do\%BE\%D0\%BF\%Do \%B8\%D1\%82\%D1\%83\%Do\%B2\%D0\%Bo\%Do\%BD\%Do\%BD\%D1\%8F_\%Do\%9A\%D0\%B 0\%D1\%80\%D0\%Bo\%Do\%BD\%D1\%82\%D0\%B8\%D0\%BD_\%D1\%82\%D0\%Bo_Covid19_\%Do \%B6\%D0\%BE\%D0\%B2\%D1\%82\%D0\%B5\%D0\%BD\%D1\%8C_2020. pdf (retrieved 20.11.2021).

Polek, T., Sanina, T., Sobol', Yu. (2021). Vplyv pandemii COVID-19 na shchodenni praktyky dytynstva. Ukrainskyi kulturnyi fond. Obtained from: https://drive.google.com/file/d/1xoXgzoEvfWEU2LooRYVHqU2-05y6PC_Y/view (retrieved 22.11.2021).

Yeremenko, A. (2020). Ukraintsiam ne podobaietsia dystantsiine navchannia. Active Group. Obtained from: https://activegroup.com.ua/2020/10/20/ ukra\%d1\%97ncyam-ne-podobayetsya-distancijne-navchannya/ (retrieved 20.11.2021).

All images (icons): Depositphotos (https://ua.depositphotos.com/) 